\title{
STUDI DAYA SERAP WARNA SERAT TANDAN PISANG DENGAN PEMBANDING SERAT ABAKA DAN SERAT SABUT KELAPA
}

\author{
A COMPARATIVE STUDY OF COLOR ABSORPTION OF BANANA \\ PEDUNCLE FIBER WITH ABACA FIBER AND COIR FIBER
}

\author{
Christmastuti Nur ${ }^{1}$, Imam Damar Djati ${ }^{2}$ \\ ${ }^{1}$ Program Studi Desain Produk, Universitas Kristen Duta Wacana \\ E-mail: christmas@staff.ukdw.ac.id \\ ${ }^{2}$ Program Studi Desain Produk, Institut Teknologi Bandung \\ E-mail: imamdj@yahoo.com
}

Tanggal diterima: 1 April 2018, direvisi: 12 Juli 2018, disetujui terbit: 20 Juli 2018

\begin{abstract}
ABSTRAK
Eksplorasi terhadap limbah tandan pisang merupakan sebuah upaya untuk mencari alternatif material produk baru. Tujuan penelitian ini untuk mengetahui karakter serat tandan pisang terutama dalam kemampuannya menyerap warna dibandingkan dengan serat abaka dan serat sabut kelapa. Uji intensitas warna dilakukan dengan cara menghitung luminansi atau intensitas cahaya yang dipantulkan kembali oleh bidang permukaan serat. Penelitian ini menunjukkan bahwa serat tandan pisang yang melalui proses pengelantangan menampilkan warna yang lebih tajam dan cerah, daripada serat yang tidak melalui proses pengelantangan. Daya serap warna serat tandan pisang yang tidak melalui proses pengelantangan sama dengan serat abaka khususnya warna merah $($ rasio $=1,00)$ dan warna biru (rasio $=1,01)$, tetapi lebih rendah dalam menyerap warna hijau (rasio $=0,98)$ dan kuning $($ rasio $=0,92)$. Maka, serat tandan pisang tanpa proses pengelantangan dapat secara efektif digunakan untuk menampilkan gradasi warna merah dan gradasi warna biru. Dibandingkan serat sabut kelapa, serat tandan pisang memiliki daya serap terhadap warna merah, hijau, biru, dan kuning yang lebih tinggi. Hasil penelitian dapat diaplikasikan dalam proses pewarnaan material produk karena mempercepat proses produksi dan menghemat biaya produksi.
\end{abstract}

Kata kunci: daya serap warna, serat tandan pisang, tingkat kecerahan warna, uji intensitas warna

\section{ABSTRACT}

Exploration of banana peduncle waste is an attempt to search new product material alternatives. The purpose of this research is to reveal the character of banana peduncle fiber especially on its ability to absorb the color compared to abaca fiber and coir fiber. The color intensity test was conducted by calculating the luminance or the intensity of light which was reflected back by the surface area of the fiber. The result of this research was the bleached banana peduncle fiber generates more vivid and brighter color than the unbleached banana peduncle fiber. The unbleached one was similar to abaca fiber especially in absorbing red color (ratio $=1.00)$ and blue color (ratio $=1.01)$, however, it was lower than abaca fiber in absorbing green color (ratio $=0.98)$ and yellow color $($ ratio $=0.92)$. Thus, the unbleached banana peduncle fiber can be used effectively to perform color gradation of red and blue. Comparing to coir fiber, the absorption of banana peduncle fiber toward red, green, blue, and yellow color was higher. This research can be applied in coloring process of product material because it can accelerate production process and save production cost.

Keywords: color absorption, banana peduncle fiber, brightness value, color intensity test

\section{PENDAHULUAN}

Keterbatasan persediaan material produk konvensional telah mendorong manusia untuk mencoba mengembangkan material di sekitarnya. Pengembangan material tersebut meliputi material polimer sintetis maupun material alam. Selama bertahun-tahun, topik mengenai material telah menjadi fokus penting dalam penelitian desain produk. ${ }^{1}$ Awalnya, material dipakai untuk menandai masa peradaban manusia. Sejak zaman pra sejarah (zaman batu, zaman perunggu, zaman besi) hingga masa kini yaitu zaman yang tidak terbatas pada satu jenis material saja tapi terbuka terhadap berbagai kemungkinan material baru serta kombinasinya. ${ }^{2}$

Eksplorasi terhadap material alam tidak terlepas dari upaya untuk mencari dan mengembangkan alternatif material baru. 
Eksplorasi material alam sangat potensial untuk diteliti di negara tropis dengan keragaman hayati seperti di Indonesia. Ketersediaan yang melimpah, sumber yang dapat diperbarui, serta dapat terurai secara alami tanpa mengkontaminasi dan membahayakan lingkungan merupakan potensi material alam yang tidak dapat diabaikan.

Salah satu upaya untuk mengeksplorasi material alam adalah dengan memanfaatkan limbah produksi hasil pertanian ${ }^{3}$ sehingga tidak mengeksploitasi sumber daya alam. Tetapi, tidak semua limbah dapat dimanfaatkan sebagai material. Limbah yang sesuai untuk dimanfaatkan sebagai bahan baku biasanya merupakan limbah yang mengalami transformasi fisis seperti pengupasan, pemotongan, penggergajian, dan tidak mengalami perubahan komposisi, baik secara kimia maupun biologis. ${ }^{4}$

Mengacu kriteria di atas, limbah tandan pisang (Gambar 1) merupakan limbah sisa produksi hasil pertanian yang prospektif. Tandan pisang termasuk dalam lignocellulosic material karena sebagian besar tersusun dari selulosa, hemiselulosa, dan lignin. ${ }^{5}$ Serat-serat selulosa inilah yang dapat dimanfaatkan sebagai material karena memiliki karakteristik berupa kekuatan mekanik yang tinggi. ${ }^{6}$ Selulosa tidak mudah terdegradasi secara kimia maupun mekanis ${ }^{7}$ sehingga sangat menguntungkan untuk digunakan sebagai material walaupun melalui proses pembersihan atau pemasakan, pengelantangan, pewarnaan, pemintalan, penggintiran, maupun pengepresan.

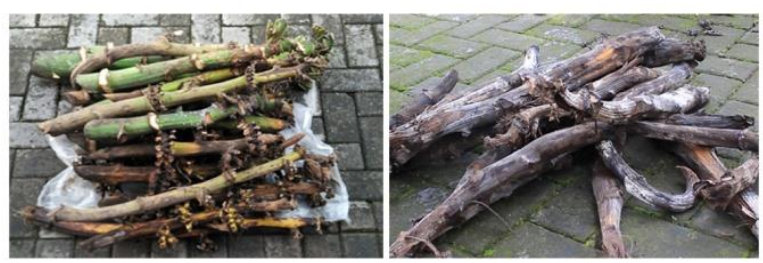

Gambar 1. Limbah Tandan Pisang

Tandan pisang dapat diperoleh dari sisa hasil panen pisang atau dari industri pengolahan makanan berbahan pisang. Batang tandan pisang dapat diuraikan menjadi serat-serat tunggal dengan cara manual maupun masinal. Penguraian secara manual misalnya dengan direndam dalam lumpur, diurai dengan tangan, atau diurai dengan sikat kawat, sedangkan penguraian secara masinal, contohnya dengan decorticator. ${ }^{8}$

$\begin{array}{rlr}\text { Pengamatan } & \text { yang dilakukan } & \text { penulis } \\ \text { terhadap sampel limbah tandan pisang }\end{array}$ menunjukkan bahwa tandan pisang memiliki panjang antara $30 \mathrm{~cm}$ hingga $92 \mathrm{~cm}$. Serat tandan pisang tergolong dalam serat panjang (filament) dengan tekstur lembut, lentur, dan lebih tipis jika dibandingan dengan serat abaka dan serat sabut kelapa. Secara visual, serat abaka lebih mengkilap (glossy) daripada serat tandan pisang. ${ }^{10}$

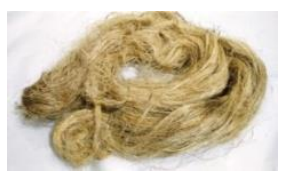

(a)

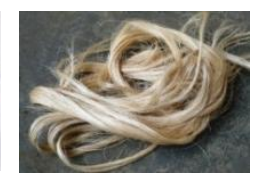

(b)

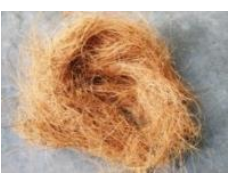

(c)
Gambar 2. (a) Serat Tandan Pisang,

(b) Serat Abaka, (c) Serat Sabut Kelapa

Eksplorasi material dari serat tandan pisang meliputi pengungkapan sifat dan karakter material tersebut. Penelitian ini bertujuan untuk mengetahui karakter serat tandan pisang terutama dalam kemampuannya menyerap warna. Penelitian dilakukan dengan membandingkan serat tandan pisang dengan serat abaka dan serat sabut kelapa melalui uji intensitas warna. Serat abaka dan serat sabut kelapa dipilih sebagai pembanding sebab kedua serat tersebut memiliki kemiripan dengan serat tandan pisang karena tergolong sebagai serat selulosa, serat panjang, serat yang kuat, mudah diperoleh, dan populer digunakan sebagai material produk.

\section{METODE}

Penelitian ini menggunakan metode eksperimen bahan yang meliputi rangkaian proses kimiawi dan semi-mekanis. Proses tersebut terbagi dalam beberapa tahap yaitu tahap persiapan bahan, yang terdiri dari membeli serat abaka siap pakai sebagai acuan (berupa benang-tali yang telah banyak dikomersialkan), dan menyiapkan bahan serat lainnya yang belum dipintal sama sekali yaitu serat abaka, serat sabut kelapa, dan serat tandan pisang. Tahap selanjutnya yaitu pembersihan dan pengelantangan (scouring dan bleaching) untuk sebagian serat tandan pisang. Langkah berikutnya memintal serat abaka, serat sabut kelapa, dan serat tandan pisang, menjadi benang-tali (cord-yarn) agar sama dengan serat abaka yang menjadi acuan. Kemudian benang tali tersebut digunakan sebagai objek pada tahap pewarnaan, tahap identifikasi warna, tahap penghitungan intensitas warna permukaan serat (penghitungan luminansi), tahap membandingkan rasio kecerahan warna antar serat, serta terakhir adalah tahap menganalisis hasil dan menarik kesimpulan. pada Gambar 3. 


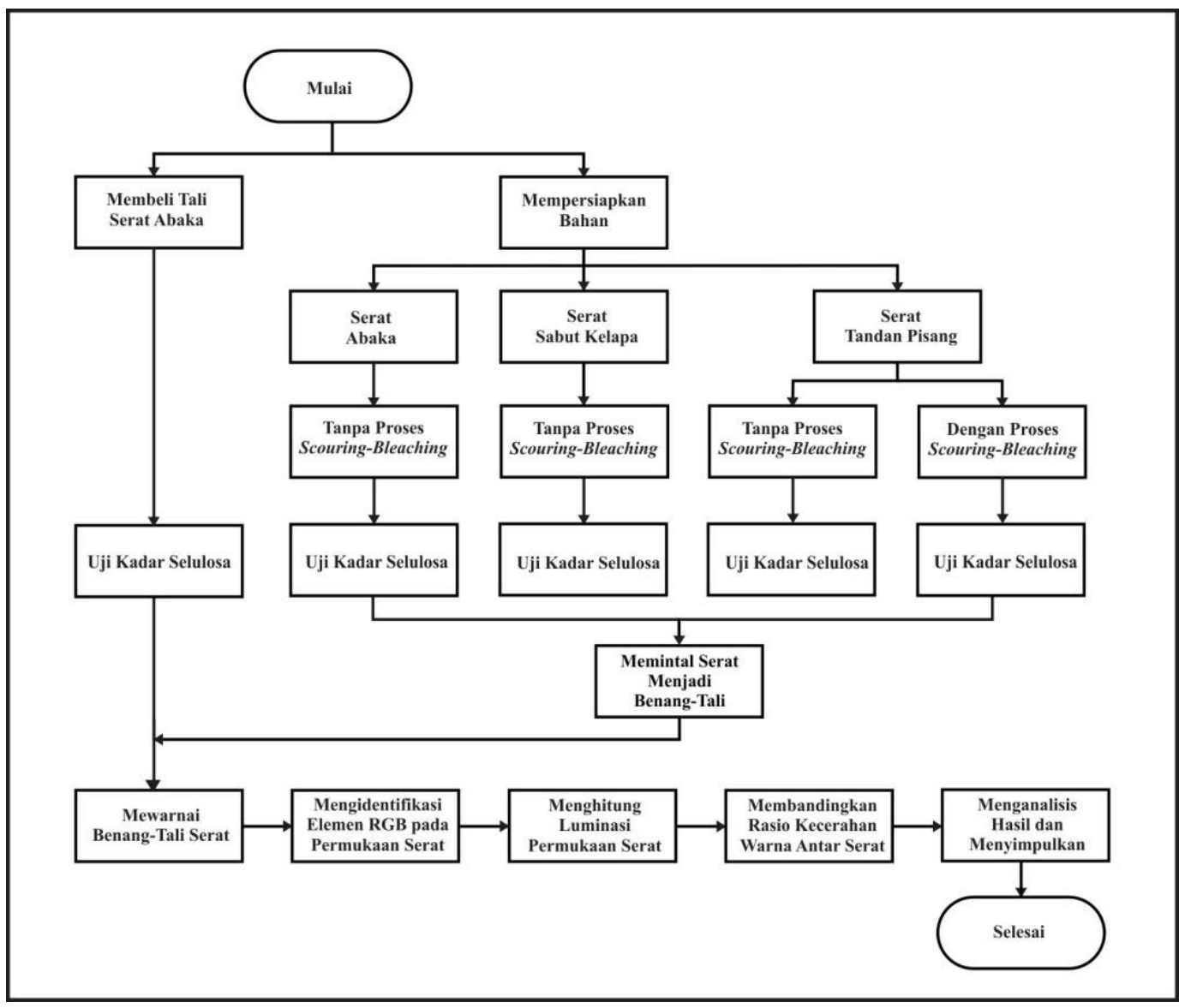

Gambar 3. Bagan Alir Penelitian

\section{Bahan}

Sampel yang digunakan terdiri dari serat tandan pisang, serat abaka, dan serat sabut kelapa. Serat tandan pisang diberikan dua perlakuan berbeda yaitu melalui proses pembersihan atau pemasakan (scouring) dan proses pengelantangan (bleaching) dan tanpa kedua proses tersebut. Pembedaan ini bertujuan untuk mengetahui pengaruh proses scouring-bleaching terhadap daya serap warna serat tandan pisang.

Seluruh serat tandan pisang yang digunakan sebagai sampel berasal dari limbah industri olahan pisang di daerah Klaten, Jawa Tengah. Batang tandan pisang yang digunakan merupakan varietas dari Pisang Raja dengan panjang rata-rata $49 \mathrm{~cm}$ dan berat rata-rata 504 gram. Serat abaka diperoleh dari tanaman Pisang Abaka di daerah Talaud, Sulawesi Utara, sedangkan serat sabut kelapa didatangkan dari daerah Bantul, Daerah Istimewa Yogyakarta.

Proses pembersihan menggunakan bahan berupa bibit sabun (teepol) dan natrium karbonat $\left(\mathrm{Na}_{2} \mathrm{CO}_{3}\right)$ atau soda abu (soda ash). Proses pengelantangan menggunakan cairan hidrogen peroksida $\left(\mathrm{H}_{2} \mathrm{O}_{2}\right)$ dan cairan natrium silikat $\left(\mathrm{Na}_{2} \mathrm{SiO}_{3}\right)$. Hidrogen peroksida $\left(\mathrm{H}_{2} \mathrm{O}_{2}\right)$ digunakan karena tidak mengandung klorin serta penguraiannya hanya menghasilkan air dan oksigen sehingga tidak membahayakan lingkungan serta kekuatan oksidatornya pun dapat diatur sesuai kebutuhan. ${ }^{10}$ Cairan natrium silikat $\left(\mathrm{Na}_{2} \mathrm{SiO}_{3}\right)$ dipilih sebagai stabilisator yang berguna untuk memperlambat penguraian hidrogen peroksida agar kerusakan serat dapat diminimalisir.

\section{Peralatan}

Penelitian dilakukan melalui beberapa tahapan: pembersihan atau pemasakan (scouring), pengelantangan (bleaching), pemintalan (spinning), pewarnaan (dyeing), dan pengujian (testing). Tahap pembersihan atau pemasakan, pengelantangan, dan pewarnaan membutuhkan alat yaitu panci, pengaduk, kompor, baskom, dan termometer air. Pemintalan serat menggunakan alat pemintal jantera (tipe: foot spindle machine) di Laboratorium Alih Teknologi, Balai Besar Tekstil yang memakai bantuan dinamo berkecepatan maksimum 6000 rpm sebagai tenaga penggeraknya. Tahap pengujian warna menggunakan aplikasi Color Intensity Meter, yang terpasang pada telepon seluler pintar dengan nilai DxOMark yang tinggi sehingga sensor kamera mendeteksi warna. Nilai DxOMark merupakan nilai benchmark yang umum digunakan dalam industri kamera. 


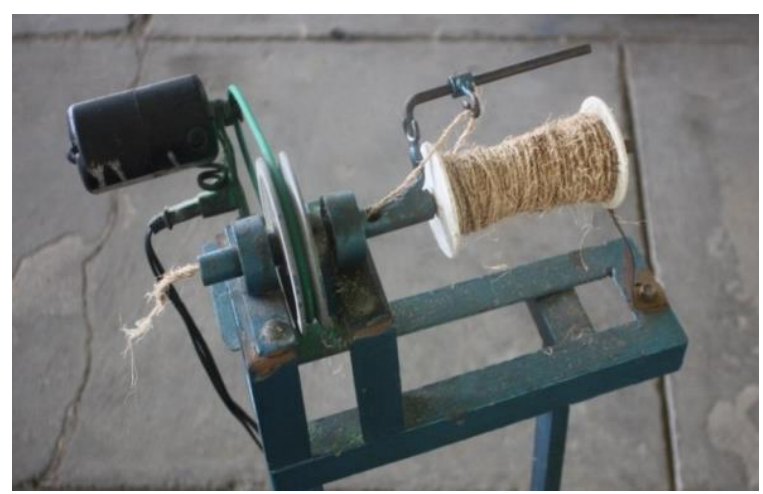

Gambar 4. Alat Pemintal Serat (Jantera)

\section{Cara}

Proses pembersihan atau pemasakan (scouring) menggunakan larutan bibit sabun (teepol) sebanyak $5 \mathrm{ml}$ dengan natrium karbonat $\left(\mathrm{Na}_{2} \mathrm{CO}_{3}\right)$ atau soda abu (soda ash) sebanyak 5 gram per liter air untuk setiap 100 gram serat. Selanjutnya serat direbus pada suhu $70^{\circ} \mathrm{C}$ selama kurang lebih 30 menit. Proses pembersihan (scouring) bertujuan untuk menghilangkan kandungan lignin (delignifikasi) yang cukup tinggi dalam batang tandan pisang sehingga diperoleh serat selulosa yang bebas dari zat-zat pengotor. Oleh karena itu, perbandingan jumlah kandungan soda abu dan teepol dalam larutan harus sesuai supaya serat tidak lengket tapi juga tidak getas.
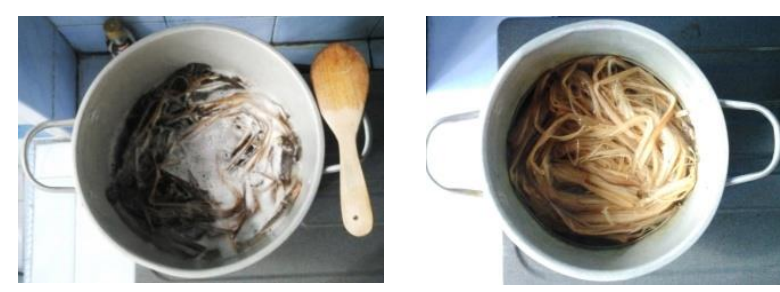

Gambar 5. Proses Scouring dan Bleaching

Proses pengelantangan (bleaching) menggunakan larutan hidrogen peroksida $\left(\mathrm{H}_{2} \mathrm{O}_{2}\right)$ sebanyak 5-10 ml dengan cairan natrium silikat $\left(\mathrm{Na}_{2} \mathrm{SiO}_{3}\right)$ sebanyak $5 \mathrm{ml}$ per liter air dan per 100 gram serat. Proses pengelantangan dilakukan dengan merebus serat di dalam larutan dengan suhu $70-85^{\circ} \mathrm{C}$ selama kurang lebih 30 menit. Sebelum dibuang, larutan sisa hasil pembersihan dan pengelantangan ditambah cuka untuk menetralkan limbah cair dan meminimalkan potensi pencemaran lingkungan.

Setelah proses pengeringan, dilakukan uji kadar selulosa dalam masing-masing jenis serat. Tujuan uji kadar selulosa ini untuk mengetahui pengaruh kadar selulosa dalam kemampuan penyerapan warna. Pengujian kadar selulosa dalam serat dilakukan dengan Metode Chesson. ${ }^{11}$ Mulamula, setiap sampel ditimbang sebanyak 1 gram (berat a), ditambahkan $150 \mathrm{ml} \mathrm{H}_{2} \mathrm{O}$, lalu direfluk pada suhu $100^{\circ} \mathrm{C}$ dengan water bath selama 1 jam. Setelah disaring, residu dicuci dengan akuades panas sebanyak $300 \mathrm{ml}$. Kemudian residu dikeringkan dengan oven hingga mencapai berat konstan dan ditimbang (berat $b$ ).

Langkah berikutnya, menambahkan $150 \mathrm{ml}$ $\mathrm{H}_{2} \mathrm{SO}_{4} 1 \mathrm{~N}$ pada residu dan direfluk dengan water bath selama 1 jam pada suhu $100^{\circ} \mathrm{C}$. Hasil disaring dan dicuci sampai netral $(300 \mathrm{ml})$. Lalu, residu dikeringkan hingga mencapai berat konstan (berat c).

Selanjutnya, menambahkan $10 \mathrm{ml} \mathrm{H}_{2} \mathrm{SO}_{4}$ $72 \%$ pada residu yang kering lalu merendam residu pada suhu kamar selama 4 jam. Kemudian, menambahkan $150 \mathrm{ml} \mathrm{H}_{2} \mathrm{SO}_{4} 1 \mathrm{~N}$ pada residu dan direfluk pada suhu $100^{\circ} \mathrm{C}$ dengan water bath selama 1 jam pada pendingin balik. Residu lalu disaring dan dicuci dengan $\mathrm{H}_{2} \mathrm{O}$ hingga netral $(400 \mathrm{ml})$.

Langkah terakhir, residu dipanaskan dengan oven dengan suhu $105^{\circ} \mathrm{C}$ hingga mencapai berat konstan dan ditimbang (berat $d$ ). Penghitungan kadar hemiselulosa dan kadar selulosa menggunakan rumus berikut.

$$
\begin{aligned}
& \text { Kadar Hemiselulosa }=\frac{b-c}{a} \times 100 \% \\
& \text { Kadar Selulosa }=\frac{(c-d)}{a} \times 100 \%
\end{aligned}
$$
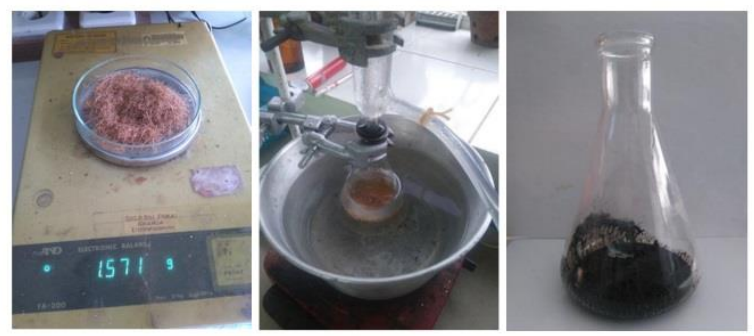

Gambar 6. Proses Uji Kadar Selulosa

Setelah melalui uji kadar selulosa, masingmasing serat dipintal menjadi benang tali (cordyarn). Pemintalan serat menjadi benang tali bertujuan untuk menyamakan dengan kondisi benang tali abaka (manila) di pasaran yang digunakan sebagai pembanding. Pemintalan serat menjadi benang tali, membuat panjang serat menjadi tidak terbatas sehingga memiliki peluang lebih luas untuk digunakan sebagai material produk. Selain itu, banyak produk berbahan serat yang menggunakan anyaman atau lilitan dari tali serat karena hasilnya lebih padat dan rapi.

Penggunaan dua jenis serat abaka bertujuan untuk mengetahui adakah perbedaan signifikan antara serat abaka yang langsung dipanen dari Talaud dengan serat abaka yang dijual di pasaran dalam wujud benang tali. Total sampel yang digunakan dalam penelitian ini sebanyak lima jenis serat, yaitu tali serat abaka yang dijual di pasar 
(kode spesimen: A), tali serat abaka yang dipanen dari Talaud (kode spesimen: B), tali serat sabut kelapa (kode spesimen: C), tali serat tandan pisang dengan proses scouring-bleaching (kode spesimen:

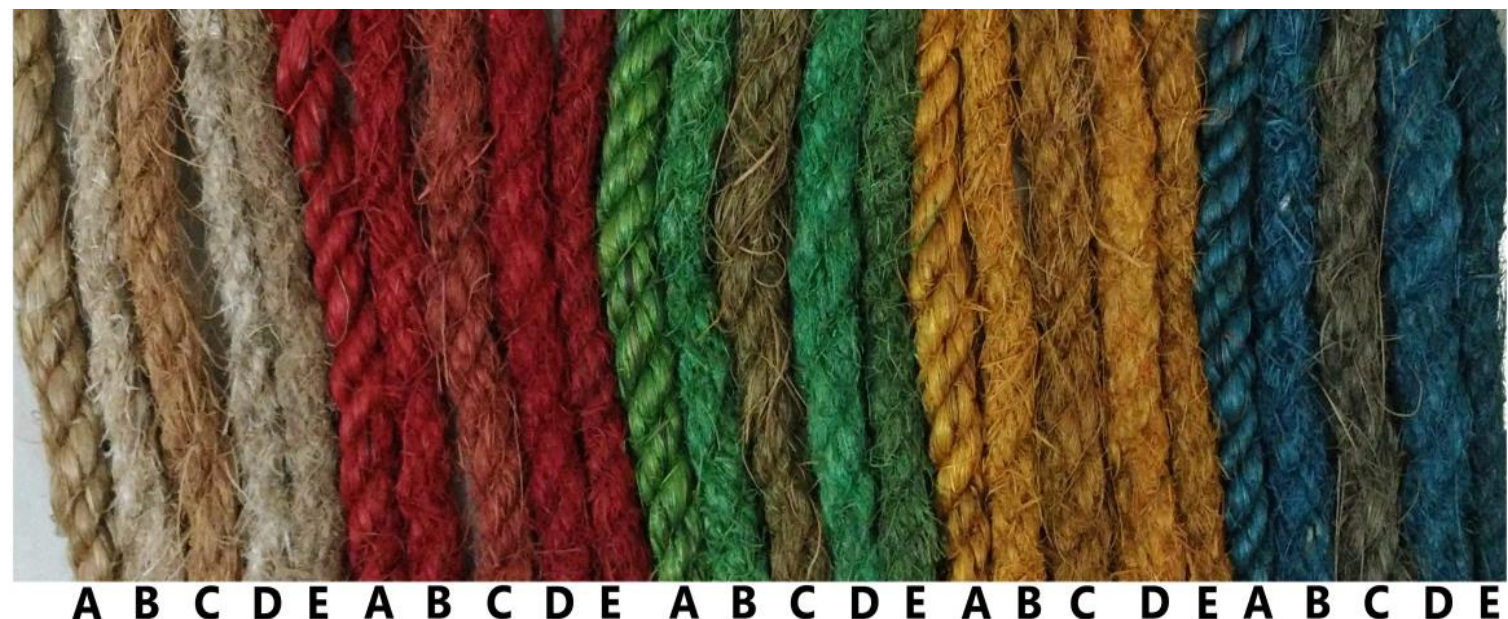

Gambar 7. Hasil Pewarnaan Serat

Keterangan:

A : Serat abaka yang dijual di pasaran

B : Serat abaka yang diperoleh dari Talaud

C : Serat sabut kelapa

D : Serat tandan pisang yang telah melalui proses scouring dan bleaching

E : Serat tandan pisang tanpa melalui proses scouring dan bleaching

D), dan tali serat tandan pisang tanpa proses scouring-bleaching (kode spesimen: E). Masingmasing jenis serat terdiri dari lima buah sampel, sehingga total sampel sebanyak dua puluh lima buah.

\section{Persiapan Pengujian}

Langkah awal pengujian yaitu mewarnai sampel serat dengan warna-warna dasar yaitu merah, hijau, biru, dan kuning. Pewarnaan serat menggunakan zat pewarna sintetis jenis Direk (Direct atau dikenal pula sebagai substantive dyes) dengan garam dapur sebagai pembangkit warnanya. Penggunaan zat warna sintetis bertujuan untuk memperoleh hasil warna yang stabil dan merata serta proses yang relatif lebih cepat karena tidak perlu melalui proses fiksasi seperti jika menggunakan zat pewarna alami. Pewarna jenis Direk dipilih karena zat warna Direk mempunyai daya afinitas yang tinggi terhadap serat selulosa sehingga umum digunakan untuk mewarnai jenis serat selulosa. ${ }^{12}$ Penetralan sisa larutan pewarnaan serat menggunakan larutan cuka agar meminimalkan dampak pencemaran lingkungan.

\section{Proses Pengujian}

Uji intensitas warna dilakukan dengan cara menghitung luminansi atau intensitas cahaya yang dipantulkan kembali oleh bidang permukaan serat. Metode ini menggunakan referensi dari metode pengujian tingkat kecerahan warna pada kayu jati muda. ${ }^{13}$
Pengujian pewarnaan serat dilakukan dengan mengukur intensitas warna (diwakili elemen RGB: Red Green Blue) yang diserap oleh masingmasing serat. Walaupun terdapat kemungkinan kurangnya akurasi, namun diusahakan pengambilan sampel warna yang paling mendekati dengan warna yang sesungguhnya serta warna yang paling banyak teridentifikasi pada permukaan tali serat. Waktu pengujian terhadap kelima jenis serat dilakukan bersamaan pada siang hari dengan kondisi cahaya \pm 20.000 lux, dan jarak sensor kamera terhadap spesimen yaitu $10 \mathrm{~cm}$.

Setelah diperoleh data elemen RGB pada masing-masing warna yang terserap oleh spesimen, maka langkah selanjutnya menghitung tingkat kecerahan warna (brightness value) yang mampu ditampilkan masing-masing spesimen. Penentuan tingkat kecerahan warna yaitu dengan menghitung intensitas cahaya yang dipantulkan kembali oleh suatu bidang permukaan atau disebut juga luminansi (luminance) dengan satuan candela $/ \mathrm{m}^{2}\left(\mathrm{~cd} / \mathrm{m}^{2}\right)$. Rumus penghitungan luminansi ditunjukkan pada persamaan berikut. ${ }^{14}$

Luminance $=(0.2126 * R)+(0.7152 * G)+$ $(0.0722 * B)$ 


\section{HASIL DAN PEMBAHASAN}

Menurut hasil kecerahan warna permukaan serat (Tabel 2) dan rasio kecerahan warna antar spesimen (Tabel 3) diperoleh hasil berikut.

1. Pada serat yang tidak diberi pewarna sama sekali (warna dasar), serat yang memiliki tingkat kecerahan paling tinggi secara berturut-turut adalah serat tandan pisang yang telah melalui scouring dan bleaching (kode spesimen: D), serat abaka dari Talaud (kode spesimen: B), serat tandan pisang tanpa proses scouring dan bleaching (kode spesimen: E), serat abaka di pasaran (kode spesimen: A), dan yang paling gelap yaitu serat sabut kelapa (kode spesimen: C).

2. Secara keseluruhan, serat abaka dari Talaud (kode spesimen: B) menyerap warna paling tinggi, karena menampilkan warna paling cerah. Selain itu, serat abaka dari Talaud juga (kode spesimen: B) menyerap warna lebih tinggi daripada serat abaka yang dijual di pasaran (kode spesimen: A). Keduanya sama-sama tidak mendapat perlakuan proses scouring-bleaching sebelumnya. Perbedaan ini disebabkan karena serat abaka berasal dari lokasi yang berbeda sehingga kualitasnya juga berbeda.

3. Rasio tingkat kecerahan warna menunjukkan bahwa serat tandan pisang yang telah melalui proses scouringbleaching (kode spesimen: D) lebih tinggi dalam menyerap warna daripada serat abaka yang ada di pasaran (kode spesimen: A).

4. Dibandingkan serat tandan pisang yang tidak melalui proses scouring-bleaching (kode spesimen: E), serat tandan pisang yang telah melalui scouring-bleaching (kode spesimen: D) menunjukkan tingkat kecerahan yang lebih tinggi, yaitu hampir mendekati dengan serat abaka dari Talaud (kode spesimen: B). Dengan demikian, untuk mendapatkan hasil warna yang paling mendekati dengan hasil warna pada serat abaka maka serat tandan pisang perlu melalui proses scouring-bleaching.

5. Serat tandan pisang yang tidak melalui proses scouring-bleaching (kode spesimen: E) memiliki daya serap warna yang sama dengan serat abaka di pasaran (kode spesimen: $\mathrm{A}$, rasio $=1,00$ ) khususnya dalam menyerap warna merah (rasio $=1,00$ ) dan warna biru (rasio $=1,01$ ), namun lebih rendah daripada serat abaka (kode spesimen: A) dalam menyerap warna hijau (rasio $=0,98)$ dan kuning (rasio $=0,92)$.

6. Serat tandan pisang yang melalui proses scouring-bleaching (kode spesimen: D), maupun tidak melalui proses scouringbleaching (kode spesimen: E), menyerap warna lebih tinggi daripada serat sabut kelapa. Tabel 3 menunjukkan rasio tingkat kecerahan serat tandan pisang lebih tinggi daripada serat sabut kelapa pada warna merah $($ rasio $=0,88)$, warna hijau (rasio $=$ 0,79 ), warna biru (rasio $=0,85$ ), maupun warna kuning (rasio $=0,87$ ). Dengan demikian, serat sabut kelapa lebih sulit menyerap dan menampilkan warna daripada serat tandan pisang.

Dibandingkan dengan serat abaka yang ada di pasaran (kode spesimen: A), serat tandan pisang yang tidak melalui proses scouring-bleaching (kode spesimen: E) memiliki daya serap yang sama, khususnya dalam menyerap warna merah (rasio $=$ $1,00)$ dan warna biru (rasio $=1,01)$. Oleh karena itu, warna merah dan biru beserta warna-warna turunannya (gradasi warna) secara efektif dapat dihasilkan dari proses pewarnaan serat tandan pisang walaupun tidak melalui proses scouring-bleaching sebelumnya.

Serat tandan pisang tanpa proses scouringbleaching dapat menyerap warna hijau (rasio $=0,98$ ) dan kuning (rasio $=0,92$ ) dengan kualitas lebih rendah daripada warna hijau dan kuning pada serat abaka yang ada di pasaran (kode spesimen: A). Oleh sebab itu, proses scouring-bleaching akan diperlukan jika membutuhkan tampilan warna-warna produk yang tajam dan cerah.

Perbedaan daya serap serat terhadap warna dalam penelitian ini salah satunya dipengaruhi oleh kadar selulosa yang terkandung dalam serat. Zat warna Direk akan bereaksi terhadap kandungan selulosa di dalam serat sehingga perbedaan daya serap warna pada tiap serat menjadi berbeda-beda. Menurut data uji kadar selulosa pada Tabel 4, serat abaka yang ada di pasaran (kode spesimen: A) maupun serat abaka dari Talaud (kode spesimen: B), merupakan serat yang memiliki kandungan selulosa tertinggi (lebih dari 55\%). Hasil uji kandungan selulosa pada serat abaka ini juga didukung dengan beberapa penelitian lain yang menyebutkan bahwa kandungan selulosa pada serat abaka antara lain 55$64 \%,{ }^{15} 62,17 \%,{ }^{16}$ dan $53,02 \% .{ }^{17}$ Kandungan selulosa pada serat abaka masih lebih tinggi daripada kandungan selulosa pada serat sabut kelapa maupun serat tandan pisang, sehingga daya serap serat abaka terhadap warna juga paling baik diantara kedua jenis serat lainnya.

Berdasarkan hasil uji kadar selulosa (Tabel 4), serat sabut kelapa (kode spesimen: C) mengandung selulosa sebesar $46,85 \%$, lebih tinggi dari yang diungkapkan dalam penelitian lain. Kandungan selulosa pada serat sabut kelapa antara lain $44,2 \%,{ }^{10} 37,2 \%,{ }^{18}$ dan $41,7 \% .{ }^{19}$ Sementara itu, pengujian terhadap serat tandan pisang menunjukkan bahwa terdapat kadar selulosa sebesar 
$44,75 \%$ pada serat tandan pisang yang melalui proses scouring-bleaching (kode spesimen: D), sedangkan pada serat tandan pisang yang tidak melalui proses scouring-bleaching (kode spesimen: E) adalah sebesar 45,25\%. Penelitian lain menyebutkan kandungan selulosa pada tandan pisang adalah sebesar $31,59 \%,{ }^{20} 48,31 \%,{ }^{21}$ hingga $51,72 \% .^{22}$ Perbedaan hasil kandungan selulosa disebabkan oleh beberapa faktor, seperti metode yang digunakan, kondisi saat pengujian berlangsung, maupun varietas tanaman serat. Walaupun serat tandan pisang yang melalui proses scouringbleaching (kode spesimen: D) mengandung selulosa lebih sedikit $(44,75 \%$ banding $45,25 \%)$ daripada serat tandan pisang yang tidak melalui proses scouring-bleaching (kode spesimen: E) tetapi serat tandan pisang yang melalui proses scouringbleaching (kode spesimen: D) justru menyerap warna lebih baik daripada serat tandan pisang yang tidak melalui proses scouring-bleaching (kode spesimen: E). Proses scouring-bleaching dapat mengurangi kadar selulosa dalam serat namun juga membantu serat dalam menyerap warna.

Membandingkan kembali hasil uji selulosa pada Tabel 4, diketahui bahwa kandungan selulosa pada serat tandan pisang $(45,25 \%)$ sedikit lebih rendah daripada serat sabut kelapa $(46,85 \%)$, namun serat tandan pisang menyerap warna lebih tinggi daripada serat sabut kelapa. Maka kadar selulosa dalam serat bukan satu-satunya penentu kemampuan suatu serat dalam menyerap zat warna. Serat tandan pisang yang memiliki kandungan selulosa terendah di antara serat abaka dan serat sabut kelapa (Tabel 4) bukan menjadi serat yang paling lemah dalam menyerap warna. Meskipun serat selulosa pada umumnya dapat diwarnai, namun tidak semua serat alam dapat menyerap warna dengan cepat, mudah, dan menghasilkan tampilan warna seperti yang diharapkan.

Tabel 1. Hasil Uji Pewarnaan Serat

\begin{tabular}{|c|c|c|c|c|c|c|}
\hline Spesimen & Warna & Red & Green & Blue & $\begin{array}{c}\text { Luminansi } \\
\left(\mathrm{cd} / \mathrm{m}^{2}\right)\end{array}$ & Rasio \\
\hline \multirow{5}{*}{ A } & Sebelum & 151 & 115 & 88 & 120.70 & 1.00 \\
\hline & Merah & 176 & 44 & 54 & 72.79 & 1.00 \\
\hline & Hijau & 107 & 130 & 82 & 121.64 & 1.00 \\
\hline & Biru & 60 & 81 & 87 & 76.97 & 1.00 \\
\hline & Kuning & 187 & 131 & 63 & 138.00 & 1.00 \\
\hline \multirow{5}{*}{ B } & Sebelum & 174 & 146 & 121 & 150.15 & 1.24 \\
\hline & Merah & 183 & 46 & 59 & 76.06 & 1.05 \\
\hline & Hijau & 101 & 148 & 109 & 135.19 & 1.11 \\
\hline & Biru & 62 & 83 & 93 & 79.26 & 1.03 \\
\hline & Kuning & 185 & 138 & 74 & 143.37 & 1.04 \\
\hline \multirow{5}{*}{$\mathrm{C}$} & Sebelum & 144 & 93 & 66 & 101.89 & 0.84 \\
\hline & Merah & 133 & 46 & 37 & 63.85 & 0.88 \\
\hline & Hijau & 123 & 92 & 59 & 96.21 & 0.79 \\
\hline & Biru & 79 & 62 & 59 & 65.40 & 0.85 \\
\hline & Kuning & 165 & 112 & 59 & 119.44 & 0.87 \\
\hline \multirow{5}{*}{$\mathrm{D}$} & Sebelum & 195 & 165 & 138 & 169.43 & 1.40 \\
\hline & Merah & 187 & 46 & 65 & 77.35 & 1.06 \\
\hline & Hijau & 116 & 137 & 94 & 129.43 & 1.06 \\
\hline & Biru & 59 & 82 & 93 & 77.90 & 1.01 \\
\hline & Kuning & 189 & 129 & 79 & 138.15 & 1.00 \\
\hline \multirow{5}{*}{$\mathrm{E}$} & Sebelum & 151 & 128 & 111 & 131.66 & 1.09 \\
\hline & Merah & 172 & 45 & 60 & 73.08 & 1.00 \\
\hline & Hijau & 124 & 122 & 74 & 118.96 & 0.98 \\
\hline & Biru & 55 & 83 & 97 & 78.06 & 1.01 \\
\hline & Kuning & 176 & 119 & 55 & 126.50 & 0.92 \\
\hline
\end{tabular}

Tabel 2. Kecerahan Warna Permukaan Serat

\begin{tabular}{|c|c|c|c|c|c|}
\hline \multirow[b]{2}{*}{ Spesimen } & \multirow{2}{*}{$\begin{array}{c}\text { Tanpa } \\
\text { Pewarna } \\
\left(\mathrm{cd} / \mathrm{m}^{2}\right) \\
\end{array}$} & \multicolumn{4}{|c|}{ Dengan Pewarna } \\
\hline & & $\begin{array}{l}\text { Merah } \\
\left(\mathbf{c d} / \mathbf{m}^{2}\right)\end{array}$ & $\begin{array}{l}\text { Hijau } \\
\left(\mathrm{cd} / \mathrm{m}^{2}\right)\end{array}$ & $\begin{array}{c}\text { Biru } \\
\left(\mathrm{cd} / \mathbf{m}^{2}\right)\end{array}$ & $\begin{array}{l}\text { Kuning } \\
\left.\mathbf{c d} / \mathbf{m}^{2}\right)\end{array}$ \\
\hline $\mathrm{A}$ & 120,7 & 72,8 & 121,6 & 76,9 & 138,0 \\
\hline $\mathrm{B}$ & 150,2 & 76,1 & 135,2 & 79,3 & 143,4 \\
\hline $\mathrm{C}$ & 101,9 & 63,9 & 96,2 & 65,4 & 119,4 \\
\hline $\mathrm{D}$ & 169,4 & 77,4 & 129,4 & 77,9 & 138,2 \\
\hline $\mathrm{E}$ & 131,7 & 73,1 & 119,0 & 78,1 & 126,5 \\
\hline
\end{tabular}


Tabel 3. Rasio Kecerahan Warna Antar Spesimen

\begin{tabular}{cccccc}
\hline \multirow{2}{*}{ Spesimen } & Tanpa & \multicolumn{4}{c}{ Dengan Pewarna } \\
\cline { 3 - 6 } & Pewarna & Merah & Hijau & Biru & Kuning \\
\hline A & 1 & 1 & 1 & 1 & 1 \\
B & 1,24 & 1,05 & 1,11 & 1,03 & 1,04 \\
C & 0,84 & 0,88 & 0,79 & 0,85 & 0,87 \\
D & 1,40 & 1,06 & 1,06 & 1,01 & 1,00 \\
E & 1,09 & 1,00 & 0,98 & 1,01 & 0,92 \\
\hline
\end{tabular}

Tabel 4. Kandungan Selulosa dalam Serat

\begin{tabular}{ccccccc}
\hline \multirow{2}{*}{ Spesimen } & \multicolumn{4}{c}{ Berat (gram) } & $\begin{array}{c}\text { Hemiselulosa } \\
(\boldsymbol{\%})\end{array}$ & $\begin{array}{c}\text { Selulosa } \\
(\boldsymbol{\%})\end{array}$ \\
\cline { 2 - 5 } & $\mathbf{a}$ & $\mathbf{b}$ & $\mathbf{c}$ & $\mathbf{d}$ & 12,55 & 55,9 \\
A & 2 & 1,674 & 1,423 & 0,305 & 12,55 & 55,55 \\
B & 2 & 1,668 & 1,382 & 0,282 & 14,3 & 46,85 \\
C & 2 & 1,696 & 1,533 & 0,596 & 8,15 & 44,75 \\
D & 2 & 1,643 & 1,319 & 0,424 & 16,2 & 45,25 \\
E & 2 & 1,585 & 1,244 & 0,339 & 17,05 & \\
\hline
\end{tabular}

Daya serap warna serat tandan pisang yang mendekati dengan daya serap warna serat abaka merupakan potensi yang sangat menguntungkan. Serat yang dapat menampilkan warna yang tajam dan cerah walaupun tanpa proses pembersihan dan pengelantangan akan dapat menekan biaya produksi serta mempercepat proses produksi karena proses pembersihan dan pengelantangan membutuhkan waktu yang tidak singkat. Dalam skala produksi yang lebih besar, kebutuhan terhadap bahan pembersih dan pengelantang juga menambah beban biaya produksi. Industri kecil yang letaknya jauh dari pusat kota juga akan terkendala karena kesulitan mencari bahan pembersih dan pengelantang serat.

Secara keseluruhan, rasio kecerahan permukaan serat tandan pisang lebih tinggi daripada serat sabut kelapa sehingga menampilkan warna yang lebih tajam dan cerah dibandingkan dengan serat kelapa. Keunggulan ini dapat menjadi potensi bagi serat tandan pisang untuk dapat dikembangkan menjadi alternatif pengganti material produk dari sabut kelapa. Oleh karena itu, nilai ekonomi yang dimiliki sabut kelapa juga dapat dimiliki oleh serat tandan pisang.

Walaupun tanpa proses scouring-bleaching, serat tandan pisang tetap memiliki karakter dapat menyerap warna dengan baik terutama warna merah dan biru. Serat yang mampu menyerap zat warna dengan baik bukan saja dapat meningkatkan nilai estetis suatu produk namun juga dapat membuka lebih banyak peluang dalam pengembangan desain produk.

Pemilihan dan penggunaan material yang tidak tepat dalam perancangan produk dapat menyebabkan permasalahan lingkungan yang sangat serius. ${ }^{23}$ Oleh karena itu, seorang desainer dituntut untuk mampu memanfaatkan material yang lebih memperhatikan keseimbangan lingkungan (ecodesain). Material serat tandan pisang merupakan contoh material yang termasuk memenuhi beberapa prinsip eco-desain ${ }^{24}$ karena merupakan material alam, material limbah, material yang dapat diperbarui, dan mudah terurai. Selain itu, kemampuan serat tandan pisang dalam menyerap zat warna dapat digunakan sebagai pertimbangan pemilihan material produk.

Pengungkapan potensi material baru seperti serat tandan pisang dapat menjadi alternatif bagi desainer untuk lebih mengembangkan desain. Semakin banyak alternatif material yang dapat dikembangkan maka semakin banyak pula tujuan dan maksud yang bisa diungkapkan atau diekspresikan oleh seorang desainer. ${ }^{25}$ Produk yang bisa dihasilkan dari material serat tandan pisang misalnya, wadah simpan, keranjang, karpet, placemats, kap lampu, sarana membawa (tas, ransel, dompet, pouch), alas dan sandaran duduk, dan lainlain.

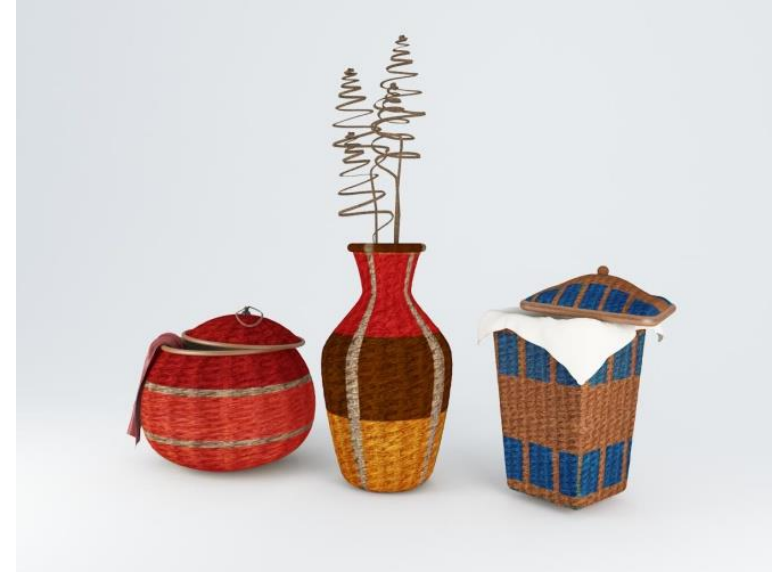

Gambar 8. Contoh Produk dari Serat Tandan Pisang

\section{KESIMPULAN}

Hasil uji intensitas warna dalam penelitian ini menghasilkan kesimpulan antara lain:

1. Untuk memperoleh tampilan warna yang mendekati dengan tampilan warna pada serat abaka, maka serat tandan pisang 
sebaiknya melalui proses scouringbleaching. Serat tandan pisang yang melalui proses scouring-bleaching menghasilkan tampilan warna yang lebih tajam dan cerah daripada serat yang tidak melalui proses scouring-bleaching.

2. Serat tandan pisang yang tidak melalui proses scouring-bleaching, secara umum memiliki daya serap warna yang sama dengan serat abaka khususnya dalam menyerap warna merah dan biru, sehingga dapat secara efektif digunakan untuk menampilkan gradasi warna merah dan gradasi warna biru.

3. Serat tandan pisang dapat diwarnai sekalipun tanpa proses scouringbleaching dengan hasil yang mendekati dengan serat abaka. Kemampuan serat tandan pisang dalam menyerap warna dapat dimanfaatkan lebih lanjut karena dapat menekan biaya produksi serta mempercepat proses produksi.

4. Serat tandan pisang yang melalui proses scouring-bleaching maupun tidak, lebih baik dalam menyerap warna dibandingkan serat sabut kelapa, sehingga menjadi salah satu keunggulan serat tandan pisang.

Eksplorasi terhadap serat tandan pisang masih perlu untuk diteliti lebih lanjut, dengan tujuan untuk mengungkap sifat-sifat dan karakter lain dari serat tandan pisang sebagai alternatif material baru. Selain itu, hal lain yang perlu diteliti pula yaitu mengenai kemungkinan-kemungkinan aplikasi produk yang dapat dikembangkan dari serat tandan pisang berdasarkan hasil studi daya serap warna dalam penelitian ini, serta respon atau minat konsumen terhadap kehadiran material baru dari serat tandan pisang.

\section{UCAPAN TERIMA KASIH}

Penelitian ini tidak akan terlaksana tanpa bantuan dari Balai Besar Tekstil (BBT), Bandung. Penulis bermaksud mengucapkan terima kasih pula kepada Bapak Mukti Widodo dan Bapak Sudaryono dari Laboratorium Alih Teknologi BBT atas segala kontribusi dan dukungannya dalam penyelesaian penelitian.

\section{PUSTAKA}

1. Karana, E., Barati, B., Rognoli, V., dan Zeeuw van der Laan, A. Material Driven Design (MDD): A Method to Design for Material Experiences, International Journal of Design, 9(2), 35-54 (2015).

2. Ashby, M., dan Johnson, K. Materials and Design: The Art and Science of Materials Selection in Product Design, Bitterworth-
Heinemann, Massachusetts, 1-3, 174-177 (2002).

3. Beylerian, George dan Dent, Andrew. Ultra Materials: How Materials Innovation is Changing the World, Thames \& Hudson, London (2007).

4. Damanhuri, Enri. dan Padmi, Tri. Pengelolaan Sampah, Diktat Kuliah TL3104 Program Studi Teknik Lingkungan, 6, Institut Teknologi Bandung (2011).

5. Khalil, A., Alwani, M.S., dan Omar, A. K. M. Chemical Composition, Anatomy, Lignin Distribution, and Cell Wall Structure of Malaysian Plant Waste Fibers. BioResources 1(2), 220-232 (2006).

6. Bahri, Syamsul. Pembuatan Pulp dari Batang Pisang. Jurnal Teknologi Kimia Unimal, Vol. 4(2), November, 36-50 (2015).

7. Mandegani, G., Sumarto, H. dan Perdana, A. Kertas Seni Berbahan Limbah Pewarna Alam Rumput Laut Jenis Sargassum, Ulva, dan Pelepah Pisang Abaka, Jurnal Dinamika Kerajinan dan Batik, Vol. 33(1), Juni, 33-44 (2016).

8. Nur, Christmastuti. Visual Characteristic of Banana Stalk Fibre Lamination as an Alternative Material for Craft Product. Prosiding $1^{\text {st }}$ ADPII International Conference of Industrial Design, 1, November 11, 74-77 (2016).

9. Nur, Christmastuti. An Alternative Of EcoFriendly Material From Banana Peduncle Waste. Proceeding of $1^{\text {st }}$ Icon-Arccade, 1, September 5-6, 212-220 (2017).

10. Wildan, Achmad. Studi Proses Pemutihan Serat Kelapa sebagai Reinforced Fibre, Tesis Program Magister Teknik Kimia, Universitas Diponegoro, 5-6, 11-12 (2010).

11. Chesson, A. Effects of sodium hydroxide on cereal straws in relation to the enhanced degradation of structural polysaccharides by rumen microorganisms. Journal of the Science of Food and Agriculture, Vol. 32 (8), 745-758, (1981).

12. Murwati, E. S., Pristiwati, E., dan Nugroho L. Teknik Pewarnaan Agel dengan Zat Warna Alam dari Daun Jati, Jurnal Dinamika Kerajinan dan Batik, Vol. 29, Juni, 21-36 (2011). 
13. Djati, Imam D., Tauchi, T., Kubo, M., dan Terauchi, F. Mechanical Properties and Characteristics of Young Teak for Making Products, The Science of Design, Bulletin of JSSD (Japan Society for the Science of Design), Vol. 62 (3), 25-34, (2015).

14. Negar, Nahid \& Williams, Drew \& Schwartz, Jaclyn \& Ahamed, Sheikh \& Smith, Roger. Smartphone-based Light Intensity Calculation Application for Accessibility Measurement. Rehabilitation Engineering and Assistive Technology Society of North America (RESNA) Conference, Indianapolis (2014).

15. Brink, M. dan Escobin, R. P. Plant Resources of South Asia: Fibre Plants No 17, Prosea Foundation, Bogor (2003).

16. Nurnasari, E. dan Nurindah. Karakteristik Kimia Serat Buah, Serat Batang, dan Serat Daun, Buletin Tanaman Tembakau, Serat \& Minyak Industri, Vol. 9(2), Oktober, 64-72 (2017).

17. Eriningsih, R., Widodo, M. dan Marlina R. Pembuatan dan Karakterisasi Peredam Suara dari Bahan Baku Serat Alam. Jurnal Arena Tekstil, Vol. 29 (1), Juni, 1-8. (2014).

18. Main, N. M., Talib, R., Ibrahim, R., Rahman, R. A., Mohamed, A. Z. Linerboard Made from Soda-Anthtaquinone (SodaAQ) Treated Coconut Coir Fiber and Effect of Pulp Beating, BioResources, 10 (4), 6975-6992 (2015).

19. Fatmawati, A., Agustriyanto, R. dan Liasari, Y. Enzymatic Hydrolisis of Alkaline
Pretreated Coconut Coir. Bulletin of Chemical Reaction Engineering \& Catalysis, Vol. 8 (1), 2013, 34-39 (2013).

20. Rahman, M. M., Nayeem, T. I. J., Jahan, M. S. Variation of Chemical and Morphological Properties of Different Parts of Banana Plant and their Effects on Pulping, International Journal of Lignocellulosic Products, 1 (2), 93-103 (2014).

21. P., Preethi dan G., Balakrishna Murthy. Physical and Chemical Properties of Banana Fibre Extracted from Commercial Banana Cultivars Grown in Tamilnadu State, Agrotechnol, S11: 008. doi:10.4172/21689881.S11-008 (2013).

22. Tavanlar, M.A.T. Ramirez, T.J. Sapin, A.B. Sedano, S.A. Banana Peduncle: to Waste or not to Waste? University of the Philippines Los Banos, National Institute of Molecular (2012).

23. McDonough, William dan Braungart, Michael. The Upcycle: Beyond Sustainability - Designing for Abundance, 211, North Point Press dan Melcher Media, New York (2013).

24. Fuad-Luke, Alastair. Eco Design: The Source Book. Thames and Hudson, London (2009).

25. Alesina, Inna dan Lupton, Ellen. Exploring Materials: Creative Design for Everyday Objects, Princeton Architectural Press, New York (2010). 